\title{
FAKTOR PENGARUH PERKAWINAN USIA MUDA DAMPAKNYA TERHADAP POLA ASUH ORANGTUA DI DESA SETIALAKSANA
}

\author{
Andri Cahyo Purnomo ${ }^{1}$ \\ Dosen STMIK Raharja ${ }^{1}$ \\ Jl. Jendral Sudirman No. 40, Modern Cikokol, Tangerang ${ }^{l}$ \\ Email : andricahyo@raharja.info ${ }^{l)}$
}

\begin{abstract}
ABSTRAK
Penelitian ini bertujuan untuk mendiskripsikan faktor yang mempengaruhi perkawinan usia muda dan untuk mendiskripsikan bentuk-bentuk pola asuh orangtua pasangan usia muda. Hasil dari penelitian ini diharapkan dapat menjadi bahan masukkan bagi para orang tua, agar tidak tergesa-gesa untuk segera menikahkan anak-anak pada usia muda. Karena usia muda disini yang bisa disebut juga usia remaja belum mampu menghadapi dan menyelesaikan persoalan-persoalan rumah tangga secara baik. Para remaja masih perlu bekal yang banyak baik bekal kedewasaan fisik, mental maupun sosial ekonomi, ilmu pengetahuan umum, agama, pengalaman-pengalaman hidup dalam kehidupan berumah tangga. Penelitian dilakukan di Desa Setialaksana Kecamatan Cabangbungin Kabupaten Bekasi. Penelitian ini merupakan penelitian deskriptif, dimana informan dalam penelitian ini adalah remaja yang telah menikah di usia muda yaitu sebanyak 20 orang dan orangtua dari informan 23 orang. Teknik pengumpulan data dengan dengan studi pustaka, studi lapangan, wawancara mendalam, triangulasi dengan expert opinion, dan observasi. Data yang didapat di lapangan kemudian dianalisis dan disusun dalam draft tanya jawab antara peneliti yang dijelaskan secara kualitatif. Hasil triangulasi dengan kepala Kantor Urusan Agama (KUA) Kecamatan Cabangbungin, didapatkan bahwa mengapa menikah muda tidak bisa hidup bahagia padahal berumahtangga yang menjadi ukuran kebahagiaan tidaklah semata-mata harta yang berlimpah namun kebahagiaan kasih sayang dan komitmen menjadi kebahagiaan yang utama. Namun ada baiknya kesiapan dari masing-masing individu untuk menikah secara lahir maupun batin jangan diabaikan begitu saja karena menikah merupakan hal penting dan sakral yang diarungi oleh pasangan sehidup semati. Hasil penelitian menunjukkan kesimpulan bahwa faktor lingkungan masyarakat dan orangtua cukup berpengaruh terhadap terhadap pembentukan konsep diri pada anak, karena si anak melihat kalau ibunya banyak yang juga melakukan pernikahan usia muda. Faktor tingkat ekonomi orangtua yang rendah banyak menyebabkan orangtua menikahkan anaknya di usia yang masih muda.

Kata kunci: faktor pernikahan usia muda, pola asuh orang tua.
\end{abstract}

\section{ABSTRACT}

This study aims to describe the factors that affect the marriage of young age and to describe the parenting patterns of young couples couples. The results of this study are expected to be an input for parents, so as not to rush to immediately marry children at a young age. Because of the young age here which can also be called adolescents have not been able to deal with and solve the problems of the household well. The teenagers still need to stock a lot of good stock of physical maturity, mental and social economy, general science, religion, life experiences in married life. The research was conducted in Setialaksana Village Branch District of Bekasi Cabangbungin. This research is descriptive research, where informant in this research is adolescent who have married at young age that is as much 20 people and parents from informant 23 people. Data collection techniques with literature study, field study, in-depth interviews, triangulation with expert opinion, and observation. The data obtained in the field then analyzed and arranged in the draft of question and answer between the researchers described qualitatively. Triangulation results with the head of the Office of Religious Affairs (KUA) Cabangbungin District, it was found that why married young can not live happily when the household is a measure of happiness is not merely wealth is abundant but the happiness of love and commitment to be the ultimate happiness. But it's good readiness of each individual to marry both 
physically and mentally should not be ignored because marriage is an important and sacred thing that is searched by the spouse semidup semati. The result of this research show conclusion that environmental factor of society and parent enough influence toward the formation of self concept in children, because the child see that many mother also do young marriage. Factors low economic level of parents cause many parents marry their children at a young age.

Keywords: Factor of marriage of young age, parent care pattern

\section{PENDAHULUAN}

Manusia dalam proses perkembangannya untuk meneruskan keturunannya membutuhkan pasangan hidup yang dapat memberikan keturunan sesuai dengan apa yang diinginkannya. Perkawinan bagi manusia merupakan hal yang penting, karena dengan sebuah perkawinan seseorang akan terbentuk keseimbangan hidup baik secara sosial biologis, menurut Hukum Islam, tidak membatasi batasan usia seseorang untuk menikah. Adanya tanda-tanda fisik seperti pubertas biologis, datangnya masa baligh bagi pria dan masa haid bagi wanita psikologis maupun secara sosial.

Perkawinan sebagai jalan untuk bisa mewujudkan suatu keluarga atau rumah tangga bahagia dan kekal berdasarkan Ketuhanan Yang Maha Esa. Hal ini dimaksudkan bahwa perkawinan itu hendaknya berlangsung seumur hidup dan tidak boleh berakhir begitu saja. Perkawinan pada umumnya dilakukan oleh orang dewasa dengan tidak memandang pada profesi, agama, suku bangsa, miskin atau kaya, tinggal di desa atau di kota. Usia perkawinan yang terlalu muda mengakibatkan meningkatnya kasus perceraian karena kurangnya kesadaran untuk bertanggungjawab dalam kehidupan berumah tangga bagi suami-istri.

Usia perkawinan yang masih muda bagi perempuan menjadi refleksi perubahan sosial ekonomi. Pergeseran ini tidak hanya berpengaruh terhadap potensi kelahiran tetapi juga terkait dengan peran dalam pembangunan bidang pendidikan dan ekonomi. Sebagaimana diketahui bahwa jumlah remaja umur 10-19 tahun di Indonesia terdapat 43 juta atau 19,61\% dari jumlah penduduk Indonesia sebanyak 220 juta, sekitar 1 juta remaja pria (5\%) dan 200 ribu remaja wanita (1\%) menyatakan secara terbuka bahwa mereka pernah melakukan hubungan seks. Sedangkan jumlah penduduk di provinsi Jawa Barat sebanyak 46.497.175 juta jiwa, terdapat beberapa kota/kabupaten yang tingkat pertumbuhan penduduknya lebih dari tingkat pertumbuhan penduduk provinsi, seperti kabupaten Bogor (2,55\%), kabupaten Bandung (1,97\%), kabupaten Bekasi (4,09\%), kota Bogor (1,81\%), kota Bekasi $(2,87 \%)$, serta kota Depok $(3,71 \%)$, adapun tempat penelitian ini terdapat di kabupaten Bekasi yang berdasarkan persentase tersebut memiliki jumlah pertumbuhan penduduk paling besar dibanding kabupaten lain di Jawa Barat, hal ini yang menjadi alasan kenapa peneliti tertarik untuk menentukan lokasi penelitian di desa Setialaksana yang termasuk kedalam salah satu wilayah Kabupaten Bekasi. ${ }^{[1]}$

Faktor utama yang menjadi alasan terjadinya perkawinan di usia muda khususnya di desa Setialaksana Rt 002/001 yaitu faktor ekonomi, orang tua tidak sanggup menyekolahkan anaknya sehingga ia cepat-cepat dinikahkan, juga karena kurangnya kemauan anak untuk melanjutkan sekolah dan karena takut akan stigma perawan tua dimasyarakat, maka satusatunya jalan keluar adalah dinikahkan secepatnya manakala ada jodohnya.

Dalam UU No. 1 tahun 1974, pasal 7 ayat (1) menyatakan bahwa perkawinan hanya diijinkan jika pihak pria sudah mencapai umur 19 dan pihak wanita sudah mencapai umur 16 tahun, usulan perubahan pada pasal 7 tahun 1974 ayat (1) perkawinan dapat dan dilakukan 
jika pihak laki-laki dan perempuan berusia minimal 19 tahun, ayat (2) untuk melangsungkan pernikahan masing-masing calon mempelai yang belum mencapai umur 21 tahun, harus mendapat izin kedua orangtua, sesuai dengan kesepakatan pihak Badan Kependudukan dan Keluarga Berencana Nasional (BKKBN) yang telah melakukan kerjasama dengan MOU yang menyatakan bahwa Usia Perkawinan Pertama diijinkan apabila pihak pria mencapai umur 25 tahun dan wanita mencapai umur 20 tahun. ${ }^{[2]}$

Namun dalam kenyataannya masih banyak kita jumpai perkawinan pada usia muda atau di bawah umur, padahal perkawinan yang sukses membutuhkan kedewasaan tanggung jawab secara fisik maupun mental, untuk bisa mewujudkan harapan yang ideal dalam kehidupan berumah tangga. Peranan orang tua sangat besar artinya bagi psikologis anak-anaknya. Mengingat keluarga adalah tempat pertama bagi tumbuh perkembangan anak sejak lahir hingga dewasa, maka pola asuh anak dalam perlu disebarluaskan pada setiap keluarga. Hasil penelitian menunjukkan bahwa penyebab terjadinya perkawinan di usia muda dipengaruhi oleh berbagai macam faktor yang mendorong mereka untuk melangsungkan perkawinan di usia muda.

Terjadinya perkawinan usia muda di Desa Setialaksana, Kecamatan Cabangbungin Kabupaten Bekasi ini mempunyai dampak tidak baik kepada mereka yang telah melangsungkan pernikahan juga berdampak pada anak-anak yang dilahirkannya serta masingmasing keluarganya. Namun tidak dapat dipungkiri bahwa tidak semua pekawinan di usia muda berdampak kurang baik bagi sebuah keluarga karena sedikit dari mereka yang telah melangsungkan perkawinan di usia muda dapat mempertahankan dan memelihara keutuhannya sesuai dengan tujuan dari perkawinan itu sendiri

Berdasarkan fakta yang ada bahwa pola asuh demokratis lebih mendorong anak menjadi mandiri dan berprestasi di bandingkan dengan anak diasuh dengan cara otoriter. Hasil pola asuh pada pasangan muda ini untuk masing-masing pengasuh adalah pola asuh demokratik. Dengan pola asuh demokratik ini orang tua tidak mengekang pada anak-anaknya dan memaksakan kehendaknya pada anak-anaknya, sebaliknya mereka memberikan kepercayaan penuh terhadap anak-anaknya untuk bisa menjalani kehidupan dimasa yang akan datang.

Hal yang penting yang harus disampaikan kepada masyarakat yang memiliki sosial ekonomi rendah hendaknya lebih meningkatkan keadaan ekonominya untuk dijadikan sebagai sumber penghasilan yang lain, masyarakat harus mengarahkan yang putus sekolah untuk mengikuti kursus-kursus keterampilan. Kepada pasangan yang belum menikah harus lebih memperhatikan dampak apa saja yang timbul dari perkawinan usia muda.

\section{PERMASALAHAN}

Berdasarkan latar belakang masalah yang telah tertulis di atas, peneliti menemukan masalah masih banyak terjadinya perkawinan usia muda di Desa Setialaksana, maka diperlukan pemahaman tentang dampak dari perkawinan di usia muda terhadap psikologis remaja dan peran serta orangtua dalam memberikan pola asuh yang tepat agar anak-anaknya bisa menahan diri untuk tidak terpengaruh oleh lingkungan dan pergaulan bebas yang bisa menimbulkan perkawinan di usia dini. Pendidikan anak yang kurang diperhatikan oleh orangtua karena keterbatasan ekonomi yang dialami juga menjadi alasan terjadinya perkawinan usia muda. Pada umumnya sesuai pengamatan yang dilakukan oleh peneliti keharmonisan rumah tangga pasangan yang menikah di usia muda rentan sekali dirundung masalah karena disebabkan oleh beberapa faktor diantaranya: usia yang belum ideal untuk 
menikah sehingga rawan terjadi cekcok, suami belum memiliki pekerjaan, tingkat pendidikan pasangan masih rendah.

\section{LANDASAN TEORI \\ Pengertian Perkawinan}

Perkawinan adalah perjanjian perikatan antara pihak seorang laki-laki dan dan seorang perempuan untuk melaksanakan kehidupan suami isteri, hidup berumah tangga, melanjutkan keturunan sesuai ketentuan agama. ${ }^{[3]}$

\section{Pengertian Usia Muda}

Usia muda adalah anak yang ada pada masa peralihan diantara masa anak-anak dan masa dewasa dimana anakanak mengalami perubahan cepat di segala bidang. Mereka bukan lagi anak-anak, baik bentuk badan, sikap dan cara berpikir dan bertindak, tetapi bukan orang dewasa yang telah matang. ${ }^{[4]}$

\section{Pengertian Perkawinan Usia Muda}

Perkawinan yang dilakukan oleh remaja di bawah umur antara 13-18 tahun yang masih belum cukup matang baik secara fisik maupun psikologis, karena berbagai faktor antara lain faktor ekonomi, sosial, budaya, penafsiran agama yang salah, pendidikan, dan akibat pergaulan bebas. Individu yang menikah pada usia muda akan cenderung bergantung pada orangtua secara finansial maupun emosional. ${ }^{[5]}$

\section{Pengertian Pola Asuh}

Pola asuh adalah kumpulan dari sikap, praktek dan ekspresi nonverbal orangtua yang bercirikan kealamian dari interaksi orangtua kepada anak sepanjang situasi yang berkembang. Penelitian kontemporer pada gaya pola asuh berasal dari penelitian terkenal Baumrind dalam anak dan keluarganya. ${ }^{[6]}$

\section{Pengertian Pola Asuh Orangtua}

Pola asuh menurut Kertamuda ${ }^{[7]}$ menyatakan bahwa, pola asuh adalah sebuah payung atau pelindung, tempat dimana aktivitas-aktivitas dan keahlian-keahlian orang dewasa ditampilkan dalam merawat anak. Orangtua dengan anaknya sebagai pribadi dan sebagai pendidik, dapat menyingkapkan pola asuh orangtua dalam mengembangkan disiplin anak yang tersirat dalam situasi dan kondisi yang bersangkutan.

\section{Dampak Perkawinan Usia Muda}

Menurut Dariyo ${ }^{[8]}$ dampak perkawinan usia muda meliputi:

Dampak terhadap suami istri

Tidak bisa dipungkiri bahwa pada pasangan suami-istri yang telah melangsungkan perkawinan di usia muda tidak bisa memenuhi atau tidak mengetahui hak dan kewajibannya sebagai suami istri. Hal tersebut timbul dikarenakan belum matangnya fisik maupun mental mereka yang cenderung keduanya memiliki sifat keegoisan yang tinggi. 
Dampak terhadap anak-anaknya

Masyarakat yang telah melangsungkan perkawinan pada usia muda atau di bawah umur akan membawa dampak. Selain berdampak pada pasangan yang melangsungkan perkawinan pada usia muda, perkawinan usia muda juga berdampak pada anak-anaknya. Karena bagi wanita yang melangsungkan perkawinan di bawah usia 20 tahun, bila hamil akan mengalami gangguan-gangguan pada kandungannya dan banyak juga dari mereka yang melahirkan anak.

Dampak terhadap masing-masing keluarga

Selain berdampak pada pasangan suami-istri dan anak-anaknya perkawinan diusia muda juga akan membawa dampak terhadap masing-masing keluarganya. Apabila perkawinan diantara anak-anak mereka lancar, sudah barang tentu akan menguntungkan orang tuanya masingmasing. Namun apabila sebaliknya keadaan rumah tangga mereka tidak bahagia dan akhirnya yang terjadi adalah perceraian.

Tabel 1 Perbandingan Dampak Perkawinan Usia Muda ${ }^{[9]}$

\begin{tabular}{|c|c|c|}
\hline No & Sasaran & Dampak \\
\hline 1. & Suami dan Isteri & $\begin{array}{l}\text {-Kurangnya memahami kesadaran hak dan } \\
\text { kewajiban sebagai suami isteri } \\
\text {-Tidak adanya keselarasan dalam } \\
\text { menjalankan bahtera rumah tangga. } \\
\text {-Adanya perselisihan-perselisihan dalam } \\
\text { kehidupan berumah tangga. }\end{array}$ \\
\hline 2. & Masing-masing keluarga & $\begin{array}{l}\text {-Berkurang beban keluarga untuk } \\
\text { memenuhi kebutuhan serta menghidupi } \\
\text { anaknya. } \\
\text {-Apabila terjadi perceraian maka } \\
\text { terputuslah tali silaturahim keluarga } \\
\text { tersebut. } \\
\text {-Dapat menguntungkan kedua belah pihak. }\end{array}$ \\
\hline 3. & Anak & $\begin{array}{l}\text {-Rendahnya tingkat kecerdasan anak } \\
\text {-Akan mengalami gangguan-gangguan } \\
\text { pada perkembangan fisik anak }\end{array}$ \\
\hline
\end{tabular}

\section{Faktor-faktor yang mempengaruhi pola asuh orangtua}

Orangtua dengan anaknya sebagai pribadi dan sebagai pendidik, dapat menyingkapkan pola asuh orangtua dalam mengembangkan disiplin anak yang tersirat dalam situasi dan kondisi yang bersangkutan. ${ }^{[10]}$

Adapun faktor-faktor yang mempengaruhi keadaan di atas ialah sebagai berikut:

Pendidikan Ibu

Pendidikan merupakan alat dimasyarakat untuk memperbaharui dirinya dalam melangsungkan kehidupan bermasyarakat.

Pengetahuan Ibu

Pengetahuan ibu tentang kesehatan dan gizi mempunyai hubungan erat dengan pendidikan. Anak dan ibu dengan latar belakang pendidikan yang tinggi akan memungkinkan akan mendapat kesempatan untuk hadir dan tumbuh dengan baik.

Aktivitas Ibu 
Kebutuhan wanita terhadap tugas dan di luar tugas sebagai ibu adalah berbeda-beda. Ada beberapa wanita yang merasa bahagia dengan peran khususnya sebagai ibu rumah tangga. Baginya tidak ada hal yang menyenangkan dari pada masa-masa kecil dan remaja yang penuh kebahagiaan kepada anak-anaknya.

\section{Status Sosial Ekonomi}

Status ekonomi dalam pengasuhan anak dipengaruhi pola oleh gaya dan pengalaman yang dimiliki serta pengetahuan yang diterimanya. Status ekonomi keluarga pasangan muda dikalangan menengah dan bawah ibu lebih condong melakukan pengetahuan dengan yang lebih cocok menurut dirinya yaitu cenderung demokratis.

\section{METODOLOGI}

\section{Tujuan Penelitian}

Tujuan penelitian yang dilakukan peneliti agar mendapatkan data yang empiris tentang faktor yang mempengaruhi terjadinya perkawinan di usia muda, dan juga mengetahui sejauh mana dampaknya yang akan ditimbulkan terhadap pola asuh orang tuanya itu.

\section{Metode Penelitian}

Tipe penelitian ini adalah penelitian deskrtiptif dengan pendekatan kualitatif yang dilakukan dengan tujuan menggambarkan atau mendeskripsikan obyek dan fenomena yang berkaitan dengan faktor-faktor yang menyebabkan terjadinya perkawinan usia muda dikalangan remaja di Desa Setialaksana Kecamatan Cabangbungin. Penelitian dilakukan di Desa Setialaksana Kecamatan Cabangbungin Kabupaten Bekasi. Alasan peneliti melakukan penelitian di Desa Setialaksana Kecamatan Cabangbungin Kabupaten Bekasi ini karena dari fakta yang ada dari tahun ke tahun jumlah remaja yang melakukan perkawinan diusia muda semakin meningkat, dan diantara mereka bahkan rela meninggalkan bangku sekolah dikarenakan ingin menikah muda dan dikarenakan tidak sanggup lagi mengikuti setiap pelajaran di sekolah.

Teknik penentuan informan yang peneliti gunakan dalam penelitian ini adalah “ Purposive Sampling “. Yaitu penarikan sampel yang ditetapkan dengan sengaja oleh peneliti, didasarkan atas kriteria yang dimaksud adalah penduduk yang berada di Desa Setialaksana Kecamatan Cabangbungin kabupaten Bekasi dengan mengambil 43 informan yaitu 20 pasangan remaja yang melakukan pernikahan usia muda dan 23 informan adalah orangtua dari remaja yang telah menikah usia muda mengenai pernikahan usia muda yang dianggap dapat menggambarkan dari apa yang dipertanyakan pada rumusan masalah.

\section{Instrumen Penelitian}

Instrumen penelitian wawancara dilakukan berdasarkan perkembangan dari jawaban informan dan key informan. Informan dalam penelitian ini terdiri dari 20 pasangan yang kawin di bawah umur dan 23 orang tua informan serta 4 orang responden yang terdiri dari pimpinan KUA, staf aparatur desa, ketua RT desa Setialaksana, karang taruna desa Setialaksana. Dalam hal ini untuk menambah validitas penelitian maka key informan yang paham betul mengenai perkawinan dijadikan sebagai expert opinion yaitu kepala KUA Kec. Cabangbungin, Kabupaten Bekasi. 


\section{Teknik Kaliberasi dan Keabsahan Data}

Teknik Triangulasi yang digunakan dengan cara:

1. Melakukan wawancara kepada Informan

2. Melakukan wawancara kepada Key Informan

3. Audit Trial

4. Triangulasi

5. Wawancara dengan Ahli (Expert Opinion)

\section{HASIL PENELITIAN YANG RELEVAN}

Beberapa penelitian yang relevan dengan penelitian ini adalah sebagai berikut:

1. Penelitian yang dilakukan oleh Laily Purnawati yang berjudul "Dampak Perkawinan Usia Muda Terhadap Pola Asuh Keluarga (Studi Di Desa Talang Kecamatan Sendang Kabupaten Tulungagung)." [11] Penelitian ini dilakukan penulis untuk menjelaskan mengenai perkawinan yang dilakukan di usia muda olah pasangan remaja, dan risiko yang dihadapi setelah melakukan perkawinan tersebut. Serta bagaimana peran orang tua dalam memberikan perlindungan bagi remaja yang sudah terlanjur melakukan perkawinan usia muda dan bagaimana pola asuh yang baik bagi anak yang melakukan pernikahan tersebut. Karena pada dasarnya perkawinan bagi manusia merupakan hal yang penting, dengan sebuah perkawinan seseorang akan memperoleh keseimbangan hidup baik secara biologis, psikologis maupun secara sosial. Kematangan emosi merupakan aspek yang sangat penting untuk menjaga kelangsungan perkawinan. Keberhasilan rumah tangga sangat banyak ditentukan oleh kematangan emosi, baik suami maupun istri. Dengan dilangsungkannya perkawinan maka status sosialnya dalam kehidupan bermasyarakat diakui sebagai pasangan suami istri, dan sah

secara hukum. Batas usia dalam melangsungkan perkawinan adalah penting dan dapat dikatakan sangat penting. Hal ini disebabkan karena didalam perkawinan menghendaki kematangan psikologis. Usia perkawinan yang terlalu muda dapat mengakibatkan meningkatnya kasus perceraian karena kurangnya kesadaran untuk bertanggungjawab dalam kehidupan berumah tangga bagi suami istri. Pernikahan yang sukses sering ditandai dengan kesiapan memikul tanggung jawab. Begitu memutuskan untuk menikah, mereka siap menanggung segala segala beban yang timbul akibat adanya pernikahan, baik menyangkut pemberian nafkah, pendidikan anak, maupun yang berkaitan dengan perlindungan, pendidikan serta pergaulan yang baik.

2. Penelitian yang dilakukan oleh Fitra Puspitasari yang berjudul, "Perkawinan Usia Muda: Faktor-Faktor Pendorong Dan Dampaknya Terhadap Pola Asuh Keluarga (Studi Kasus Di Desa Mandalagiri Kecamatan Leuwisari Kabupaten Tasikmalaya)." [12] Penelitian ini dilakukan penulis untuk menjelaskan mengenai faktor yang mendorong terjadinya perkawinan usia muda, dan bagaimana peran pola asuh keluarga yang dilakukan oleh orang tua terhadap anaknya yang melakukan perkawinan usia muda. Karena pada dasarnya manusia dalam proses perkembangannya untuk meneruskan jenisnya membutuhkan pasangan hidup yang dapat memberikan keturunan sesuai dengan apa yang ingin diinginkannya. Perkawinan sebagai jalan untuk bisa mewujudkan suatu keluarga atau rumah tangga bahagia dan kekal berdasarkan Ketuhanan Yang Maha Esa. Hal ini dimaksudkan bahwa perkawinan itu hendaknyaberlangsung seumur hidup dan tidak boleh berakhir begitu saja. Perkawinan pada umumnya dilakukan oleh orang dewasa dengan tidak memandang pada profesi, agama, suku bangsa, miskin atau kaya, tinggal di desa atau di kota. Usia perkawinan yang terlalu muda mengakibatkan meningkatnya kasus 
perceraian karena kurangnya kesadaran untuk bertanggungjawab dalam kehidupan berumah tangga bagi suami-istri.Permasalahan dalam penelitian ini yaitu: Faktorfaktor apa saja yang mendorong perkawinan usia muda. Bagaimana dampak yang dialami oleh mereka yang melangsungkan perkawinan usia muda, serta Bagaimana bentuk pola asuh keluarga pasangan usia muda. Tujuan yang hendak dicapai dalam penilaian ini adalah; Mendiskripsikan faktor-faktoryang mendorong terjadinya perkawinan usia muda di desa Mandalagiri kecamatan Leuwisari kabupaten Tasikmalaya.

3. Penelitian yang dilakukan oleh Siti Yuli Astuti yang berjudul "Faktor-Faktor Penyebab Terjadinya Perkawinan Usia Muda Dikalangan Remaja Di Desa Tembung Kecamatan Percut Sei Tuan Kabupaten Deli Serdang" ${ }^{[13]}$. Penelitian ini dilakukan penulis untuk menjelaskan mengenai faktor yang menyebabkan seringnya perkawinan usia muda terjadi dikalangan remaja khususnya di desa Tembung Kecamatan Percut Sei Tuan Kabupaten Deli Serdang. Penelitian ini bertujuan untuk mendiskripsikan faktor-faktor yang menyebabkan terjadinya perkawinan usia muda dikalangan remaja dan untuk mendiskripsikan bentukbentuk pola asuh keluarga pasangan usia muda. Hasil dari penelitian ini diharapkan dapat menjadi bahan masukkan bagi para orang tua, agar tidak tergesa-gesa untuk segera menikahkan anak-anak pada usia remaja. Karena usia remaja belum mampu menghadapi dan menyelesaikan persoalan-persoalan rumah tangga secara baik. Para remaja masih perlu bekal yang banyak baik bekal kedewasaan fisik, mental maupun sosial ekonomi, ilmu pengetahuan umum, agama, pengalamanpengalaman hidup dalam kehidupan berumah tangga. Faktor lingkungan masyarakat dan orangtua cukup berpengaruh terhadap terhadap pembentukan konsep diri pada anak, karena si anak melihat kalau ibunya banyak yang juga melakukan pernikahan dini. Faktor tingkat ekonomi orangtua yang rendah banyak menyebabkan orangtua menikahkan anaknya di usia yang masih muda.

\section{HASIL DAN PEMBAHASAN}

Usia perkawinan pertama bagi perempuan menjadi refleksi perubahan sosial ekonomi. Pergeseran ini sangat berpengaruh terhadap potensi kelahiran tetapi juga bidang pendidikan dan ekonomi. Dari penelitian yang dilakukan di Desa Tembung, sejak masa survey awal, observasi hingga proses penelitian itu sendiri, dapat diketahui bahwa dari 45.230 jiwa penduduk Desa Setialaksana terdapat \pm 9.745 pasangan remaja dengan tingkat pendidikan yang rendah yang sudah menikah di usia muda dan kebanyakan dari mereka yang menikah di usia muda adalah remaja wanita dan diantaranya masih hamil anak pertama dan sudah pernah melahirkan, seperti pada tabel berikut ini :

Tabel 2. persentase wanita usia 15-18 tahun yang sudah menjadi ibu atau hamil anak pertama dengan tingkat pendidikan terakhir tahun 2011. ${ }^{[14]}$

\begin{tabular}{|c|c|c|c|c|}
\hline \multirow[b]{2}{*}{ Pendidikan } & \multicolumn{3}{|c|}{ Persentase (\%) } & \multirow[b]{2}{*}{$\begin{array}{l}\text { Presentase Yang } \\
\text { Sudah Pernah } \\
\text { Melahirkan }\end{array}$} \\
\hline & $\begin{array}{l}\text { Jumlah } \\
\text { Yang } \\
\text { Menikah } \\
\text { Muda }\end{array}$ & $\begin{array}{r}\text { Remaja } \\
\text { Sudah } \\
\text { Diusia }\end{array}$ & $\begin{array}{l}\text { Jumlah Remaja } \\
\text { Yang Hamil Anak } \\
\text { Pertama }\end{array}$ & \\
\hline Tidak Sekolah & \multicolumn{2}{|c|}{$15,5 \%$} & $5,6 \%$ & $22,2 \%$ \\
\hline Tidak Tamat SD & \multicolumn{2}{|c|}{$16,3 \%$} & $3,5 \%$ & $21,0 \%$ \\
\hline SD & \multicolumn{2}{|c|}{$16,2 \%$} & $4,1 \%$ & $21,5 \%$ \\
\hline Tidak Tamat SMP & \multicolumn{2}{|c|}{$3,2 \%$} & $1,1 \%$ & $4,19 \%$ \\
\hline
\end{tabular}

Sumber : Kantor Kepala Desa Setialaksana 2011 
Data di atas menunjukkan bahwa banyak perempuan dalam usia muda yang sudah kawin atau sudah (terpaksa) hamil di usia-usia sekolah dasar kebawah sehingga terpaksa putus sekolah tidak dapat melanjutkan pendidikan kejenjang yang lebih tinggi. Ini artinya dengan berbagai alasan perempuan di usia dini harus sudah kawin dan hamil tanpa kuasa berbuat banyak untuk masa depannya. Angka ini terus melonjak mengingat semakin meningkatnya penduduk Desa Setialaksana, maka semakin meningkat pula pengaruh budaya yang masuk ke Desa Setialaksana yang dapat mempengaruhi remaja-remaja di Desa Setialaksana terutama remaja usia belia yang mengakibatkan meningkatnya angka remaja yang menikah diusia muda.

\section{Tingkat pendidikan orangtua}

Tingkat pendidikan orang tua di desa Setialaksana Rt 002/001, dapat dilihat dari pendidikan formal. Berdasarkan data pendidikan formal ayah yang diperoleh dari 38 responden, yang terdiri dari 20 pasangan usia muda dan 18 orangtua pasangan usia muda. Dari pasangan usia muda, suami terdapat 14 orang berpendidikan SMP, 5 orang berpendidikan SD, 1 orang berpendidikan MTS. Pendidikan Isteri, 11 orang berpendidikan SMP, 6 orang berpendidikan SD, 2 orang berpendidikan MTS, tidak sekolah 1 orang. Tampak bahwa mayoritas pendidikan ayah dari pasangan suami istri tersebut berpendidikan SD dan SMP. Demikian juga dengan pendidikan ibu, terdapat 10 orang berpendidikan SMP, dan 6 orang berpendidikan SD, dan ada 1 orang yang tidak bersekolah.

Tabel 3. Tingkat pendidikan orangtua

\begin{tabular}{|c|c|l|}
\hline Tingkat Pendidikan & Ayah & Ibu \\
\hline SD & 5 & 6 \\
SMP & 14 & 11 \\
MTS & 1 & 2 \\
Tidak Bersekolah & - & 1 \\
\hline Total & 20 & 20 \\
\hline
\end{tabular}

\section{Jenis pekerjaan orangtua}

Pekerjaan ayah dari pasangan suami-istri yang menikah pada usia muda sebagian besar adalah wiraswasta (11 orang) diikuti petani, (2), karyawan (1 orang), orang) pedagang (5 orang). Sedangkan pekerjaan ibu, ibu rumah tangga (19 orang ), karyawan (1 orang).

Tabel 4. Jenis pekerjaan orangtua

\begin{tabular}{|l|c|l|}
\hline \multicolumn{1}{|c|}{ Jenis Pekerjaan } & Ayah & Ibu \\
\hline Wiraswasta & 11 & - \\
karyawan & 1 & 1 \\
Petani & 2 & - \\
Pedagang & 5 & - \\
Ibu Rumah Tangga & - & 19 \\
\hline \multicolumn{1}{|c|}{ Total } & 16 & 16 \\
\hline
\end{tabular}

Masalah perkawinan usia muda dikalangan remaja memiliki tingkat masalah yang sama dengan daerah lain, terutama daerah yang memilki tingkat penduduk yang padat, dengan tingkat ekonomi masyarakatnya yang rendah. Dimana kebanyakan remaja yang telah menikah di usia yang relatif masih sangat muda hidup dengan latar belakang dari rendahnya ekonomi 
orangtua, pengaruh lingkungan sosial yang sangat mendorong remaja untuk memutuskan menikah di usia yang masih muda, serta kurangnya perhatian dan rendahnya pendidikan yang dimiliki oleh keluarga.

Untuk lebih memperjelas data yang ada, peneliti melakukan wawancara mendalam terhadap 3 informan atau 3 orang remaja yang menikah di usia muda, 3 informan ini mewakili jumlah pasangan remaja yang menikah di usia muda di Desa Setialaksana Kecamatan Cabangbungin Kabupaten Bekasi :

\section{Informan 1}

Informan 1 menikah pada usia 17 tahun, informan sudah menjadi perokok tetap sejak duduk di bangku sekolah. Orangtua informan memperbolehkan informan menikah di usia muda dikarenakan orangtua informan sudah dekat dengan suami informan, suami informan yang sudah mapan, sehingga informan dapat membantu ekonomi keluarga informan. Latar belakang keluarga informan yang ternyata juga menikah di usia muda. Keinginan informan menikah di usia muda adanya pengaruh dari lingkungan pergaulan yang kebanyakan dari teman-teman korban sudah menikah dini dan sudah mempunyai anak.

\section{Informan 2}

Informan 2 menikah pada usia 16 tahun, informan juga perokok tetap sejak duduk dibangku sekolah, orangtua informan sudah lama mengenal suami informan, sehingga orangtua informan menyetujui informan menikah pada usia muda. Ekonomi suami informan yang sudah mapan juga menjadi salah satu faktor mengapa orangtua informan menyetujui anaknya menikah di usia yang masih muda. Menikah dini merupakan keinginan imforman dari dalam hati, tanpa ada paksaan dari pihak manapun.

\section{Informan 3}

Informan 3 menikah pada usia 17 tahun, orangtua informan memperbolehkan informan menikah di usia muda dengan alasan suami informan yang sudah mapan. Latar belakang keluarga informan yang kebanyakan menikah di usia muda dulunya, membuat informan ingin menikah di usia muda seperti kakak-kakaknya, jawaban yang dilontarkan oleh informan ke 3 hampir sama dengan informan yang ke 2, yaitu keinginan informan menikah di usia muda karena adanya pengaruh dari pergaulan informan, kebanyakan teman-teman informan sudah menikah di usia muda dan sudah mempunyai anak.

Berdasarakan hasil wawancara yang dilakukan oleh peneliti terhadap ke 3 orang informan atau 3 pasangan yang menikah di usia muda yaitu tampak bahwa faktor yang paling dominan mempengaruhi menyebabkan seorang remaja melakukan perkawinan usia muda adalah faktor orangtua, rendahnya ekonomi orangtua mempunyai dampak yang besar terhadap perkembangan remaja dan masa depan remaja itu sendiri, orangtua merasa malu bila anak perempuannya terlambat kawin dan jadi perawan tua serta dianggap tidak laku. Faktor pergaulan pertemanan atau lingkungan masyarakat tempat informan tinggal termasuk salah satu faktor seseorang melakukan perkawinan di usia muda. Faktor lain yang menyebabkan seorang remaja melakukan perkawinan usia muda di Desa Setialaksana dapat diklasifikasikan ke dalam tiga kategori yang saling berhubungan, yakni inisiatif atau dorongan dari anak itu sendiri, pola asuh keluarga, dan ekonomi keluarga. Ketiga faktor ini memberikan pengaruh secara tidak langsung terhadap perilaku seorang remaja dalam menentukan masa depan mereka. Selain 3 faktor di atas terdapat juga beberapa faktor lain yang menyebabkan perkawinan di usia muda, yaitu : 
1. Peran gender dan kurangnya alternatif (Gender roles and a lack of alternatives),

2. Nilai virginitas dan ketakutan mengenai aktivitas seksual pranikah (value of virginity and fears about premarital sexual activity).

3. Pernikahan sebagai usaha untuk menggabungkan dan transaksi (marriege alliances and transactions) dan

4. Kemiskinan (the role of poverty)

\section{Analisis}

Berdasarkan temuan di atas, ditemukan sebuah gambaran yang menjelaskan bahwa terdapat sebuah bahwa kemiskinan yang terjadi di dalam sebuah keluarga sangat berdampak besar terhadap masa depan seorang anak, terutama pada anak remaja. Seorang remaja yang seharusnya melanjutkan tugas perkembangan sesuai dengan usianya, kini harus menikah dengan usia yang masih muda dengan hanya memiliki tingkat pendidikan yang rendah. Orangtua yang memiliki tingkat ekonomi yang rendah selalu tergesa-gesa untuk menikahkan anak perempuannya di usia muda. Hal ini dilakukan oleh para orangtua agar bisa mengalihkan beban mereka kepada menantunya.

Hal ini kemudian didukung oleh kategori pola asuh orangtua yang demokratik dimana pola asuh ini kurang signifikan dikarenakan orangtua tidak mengekang pada anak-anaknya dan memaksakan kehendaknya pada anak-anaknya, sebaliknya mereka memberikan kepercayaan atau kebebasan terhadapa anak-anaknya untuk bisa menjalani kehidupan dimasa yang akan mendatang. Pola asuh orangtua tersebut seperti kurangnya nasehat yang diberikan kepada anak mengenai bahayanya menikah di usia muda dan kehidupan dalam menjalani rumah tangga dengan usia yang relatif masih sangat muda dan peranan orangtua yang sangat dominan dalam menentukan perkawinan anak perempuan, karena anggapan bahwa anak adalah milik, sehingga anak terutama anak perempuan harus senantiasa berbakti/patuh kepada orangtua. Kurangnya perhatian pmerintah dalam menangani kasus perkawinan dibawah umur, seperti Undang-Undang Perkawinan No. 1 tahun 1974 yang memperbolehkan pernikahan anak perempuan pada usia 16 tahun dan laki-laki 19 tahun, yang seharusnya sudah terdapat perubahan karena sudah tidak sesuai dengan keadaan saat ini.

Dari penelitian yang telah dilakukan, peneliti mencoba menganalisis hasil wawancara peneliti dengan informan. Peneliti dapat menganalisa tentang konsep diri remaja dalam pernikahan dini dengan 3 orang informan, yang terdiri dari informan pertama yang berumur 19 tahun, informan keduan berumur 16 tahun, dan informan ketiga berumur 18 tahun, ketiga informan tersebut telah melakukan pernikahan di usia muda. Untuk menambah informasi dan data, peneliti juga mewawancari orangtua dari salah satu informan.

Terdapat beberapa faktor yang dianalisis pada poin ini, yaitu :

1. Faktor orangtua dalam pembentukan konsep diri remaja yang melakukan perkawinan diusia muda, dari hasil wawancara mendalam terhadap ke 3 informan dapat ditarik kesimpulan bahwa remaja yang sudah melakukan pernikahan dini hampir semuanya disetujui oleh orangtua mereka masing-masing. Pandangan orangtua msing-masing pun berbeda-beda, salah seorang orangtua informan beranggapan apabila calon suami yang ingin menikahi anaknya sudah mapan lahir batin dan sudah sanggup untuk berumah tangga, sehingga apa salahnya kalau manikah diusia muda dan ada yang beranggapan selama satu iman atau seagama maka orangtua membolehkan anaknya menikah di usia muda ditambah kahidupan ekonomi calon yang sudah mencukupi. Faktor orang tua merupakan faktor adanya perkawinan usia muda, dimana orang tua akan segera menikahkan anaknya jika sudah 
menginjak besar. Hal ini merupakan hal yang sudah biasa atau turun-temurun. Sebuah keluarga yang mempunyai anak gadis tidak akan merasa tenang sebelum anak gadisnya menikah. Orangtua akan merasa takut apabila anaknya jadi perawan tua dan takut apabila anaknya akan melakukan hal-hal yang tidak diinginkan yang akan mencemari nama baik keluarganya. Jika si anak belum juga mendapatkan jodohnya, maka orang tua ikut mencarikan jodoh buat anaknya dengan catatan jodoh yang akan di berikannya itu sesuai dengan keinginan anaknya atau disetujui oleh anaknya.

2. Faktor kelompok rujukan dalam konsep diri remaja remaja yang melakukan perkawinan diusia muda, setiap kelompok mempunyai norma-norma tertentu. Ada kelompok yang secara emosional mengikat kita dan berpengaruh terhadap pemebentukan konsep diri kita, komunikasi terjalin antara informan-informan dengan lingkungan masyarakatnya pun berjalan dengan baik, dari wawancara peneliti dengan informan dapat dijelaskan bahwa informan tidak merasa dibedakan dengan remaja-remaja lain yang belum menikah, komunikasi masih terjalin dengan hangat. Walaupu ada salah satu informan yang tidak terlalu dekat dengan tetangga-tetangga di lingkungan rumahnya, hal itu dikarenakan informan sudah tinggal dengaan orangtuanya tetapi berdua dengan suaminya. Dan di lingkungan rumahnya memang tetangga yang satu kurang akrab dengan tetangga yang lainnya, jadi kurang adanya komunikasi yang baik di lingkungan rumahnya.

3. Konsep diri remaja di Desa Setialaksana Kecamatan Cabangbungin Kabupaten Bekasi. Konsep diri remaja yang melakukan perkawinan diusia muda yang sudah dipaparkan oleh informan-informan, kalau setelah mereka melakukan perkawinannya sama sekali tidak membuat mereka minder atau tidak percaya diri baik di lingkungan masyarakat dan lingkungan pergaulan mereka. Setelah menikah mereka masih bisa bergaul dengan baik meskipun salah satu dari mereka setelah menikah dini sedikit membatasi pergaulannya, karena sudah mempunyai tanggung jawab mengurus rumah tangga dan suami. Dan semua informan memaparkan tanggapannya yang hampir semuanya sama, kalau menikah dini itu menyenangkan walaupun bagi beberapa orang menikah dini adalah pernikahan main-main karena belum cukup umur, emosi yang masih labil.

4. Faktor ekonomi, Adanya perkawinan usia muda di Desa Setialaksana sebagian besar disebabkan kerena kondisi ekonomi keluarga yang kurang. Para orang tua yang menikahkan anaknya pada usia muda mengganggap bahwa dengan menikahkan anaknya beban ekonomi keluarga akan berkurang satu. Hal ini disebabkan karena jika anak sudah menikah, maka akan menjadi tanggung jawab suaminya. Bahkan para orang tua berharap jika anaknya sudah menikah dapat membantu kehidupan orang tuanya. Di desa Setialaksana kecamatan Cabangbungin kabupaten Bekasi, kondisi ekonomi setiap keluarganya antara satu keluarga dengan keluarga yang lainnya berbeda. Tidak semua keluarga di desa tersebut bisa memenuhi semua keperluan sehari-harinya karena penghasilan yang mereka peroleh belum bisa memadai untuk digunakan keperluan seharihari. Masyarakat di desa Setialaksana mempunyai mata pencaharian yang beraneka ragam. Diantara mereka ada yang memiliki pekerjaan tetap juga pekerjaan tidak tetap. Oleh karena itu untuk penghasilan yang mereka peroleh setiap harinya tidak menentu. Di desa Setialaksana, kondisi ekonomi setiap keluarga dapat digolongkan pada beberapa tahap yaitu tahap ekonomi lemah, tahap ekonomi menengah atas dan menegah ke bawah serta tahap ekonomi atas (kaya). Setiap tahapan tersebut penghasilan yang mereka peroleh berbeda ada yang cukup, sedang dan lebih. Di bawah ini tabel tahapan keluarga sejahtera yang didapatkan dari Kantor Kepala Desa Setialaksana, Kecamatan Cabangbungin Kabupaten Bekasi. 
Tabel 5. Tahapan keluarga sejahtera

\begin{tabular}{|c|c|c|c|c|c|c|c|c|c|c|c|c|c|}
\hline \multirow[t]{2}{*}{ No } & \multirow[t]{2}{*}{ Rw } & \multirow[t]{2}{*}{$\begin{array}{l}\text { Jml. } \\
\text { Rt }\end{array}$} & \multirow{2}{*}{$\begin{array}{l}\text { Jml. } \\
\text { Rmh } \\
\text { Tang } \\
\text { ga }\end{array}$} & \multirow{2}{*}{$\begin{array}{c}\text { Jml. } \\
\text { Kepal } \\
\text { a } \\
\text { Kelua } \\
\text { rga } \\
\end{array}$} & \multicolumn{2}{|c|}{$\begin{array}{lr}\text { Jumlah } & \text { Kepala } \\
\text { Keluarga } & \text { menurut } \\
\text { status perkawinan }\end{array}$} & \multicolumn{2}{|c|}{$\begin{array}{l}\text { Jumlah jiwa } \\
\text { dalam } \\
\text { keluarga }\end{array}$} & \multirow{2}{*}{$\begin{array}{l}\text { त्र } \\
\text { 중 }\end{array}$} & \multirow{2}{*}{$\begin{array}{l}\text { त } \\
\sim \\
-\end{array}$} & \multirow{2}{*}{$\begin{array}{l}\pi \\
\sim \\
N\end{array}$} & \multirow{2}{*}{$\begin{array}{l}\text { त्र } \\
\omega \\
\omega\end{array}$} & \multirow{2}{*}{$\begin{array}{l}\text { त् } \\
\Delta \\
\Delta\end{array}$} \\
\hline & & & & & Kawin & Duda/Janda & $\mathrm{L}$ & $\mathrm{P}$ & & & & & \\
\hline 1 & $\begin{array}{l}\text { Dusun } \\
\text { I Garon } \\
\text { Barat }\end{array}$ & 4 & 354 & 561 & 459 & 102 & 963 & 883 & 405 & $\begin{array}{l}8 \\
9\end{array}$ & $\begin{array}{l}3 \\
5\end{array}$ & $\begin{array}{l}2 \\
2\end{array}$ & 5 \\
\hline 2 & $\begin{array}{l}\text { Dusun } \\
\text { II } \\
\text { Garon } \\
\text { Tengah }\end{array}$ & 3 & 249 & 526 & 433 & 93 & 898 & 842 & 388 & $\begin{array}{l}7 \\
9\end{array}$ & $\begin{array}{l}3 \\
2\end{array}$ & $\begin{array}{l}2 \\
1\end{array}$ & 6 \\
\hline 3 & $\begin{array}{l}\text { Dusun } \\
\text { III } \\
\text { Garon } \\
\text { Timur }\end{array}$ & 4 & 401 & 553 & 465 & 88 & 907 & 895 & 379 & $\begin{array}{l}9 \\
0\end{array}$ & $\begin{array}{l}3 \\
8\end{array}$ & $\begin{array}{l}4 \\
0\end{array}$ & 6 \\
\hline 4 & Jumlah & 11 & 1004 & 1640 & 1357 & 283 & $\begin{array}{l}276 \\
8\end{array}$ & 2620 & 1172 & $\begin{array}{l}2 \\
5 \\
8\end{array}$ & $\begin{array}{l}1 \\
0 \\
5\end{array}$ & $\begin{array}{l}8 \\
3\end{array}$ & 17 \\
\hline
\end{tabular}

Berdasarkan tabel tahapan keluarga sejahtera Desa Setialaksana jumlah PRA Keluarga Sejahtera atau keluarga miskin cukup banyak yaitu 1172 Kepala Keluarga.

5. Faktor diri sendiri, Selain faktor ekonomi, perkawinan usia muda di desa Setialaksana disebabkan adanya kemauan sendiri dari pasangan. Hal ini disebabkan adanya pengetahuan anak yang diperoleh dari film atau media-media yang lain, sehingga bagi mereka yang telah mempunyai pasangan atau kekasih terpengaruh untuk melakukan pernikahan di usia muda. maka dapat disimpulkan bahwa perkawinan usia muda selain karena keadaan ekonomi orang tua yang tidak mencukupi, juga karena kehendak dan kemauan sendiri.

6. Faktor pendidikan, rendahnya pendidikian juga merupakan faktor terjadinya pernikahan usia muda. Para orang tua yang hanya bersekolah hingga tamat SD merasa senang jika anaknya sudah ada yang menyukai, dan orang tua tidak mengetahui adanya akibat dari pernikahan muda ini. Disamping perekonomian yang kurang pendidikan orang tua yang rendah, akan membuat pola pikir yang sempit. Sehingga akan mempengaruhi orang tua untuk segera menikahkan anak perempuannya.

7. Faktor kebiasaan dan tradisi, alasan kebiasaan dan tradisi menjadi salah satu faktor terjadinya perkawinan usia muda, yang lebih memprihatinkan antara orang tua dan anak sama-sama menganggap perkawinan usia muda merupakan hal biasa dan juga dianggap tradisi di masyarakat. Banyak sekali orang tua di desa Setialaksana kecamatan Cabangbungin Kabupaten Bekasi yang menikahkan anak perempuannya pada usia yang masih muda. Kebanyakan dari mereka yang telah menikahkan anaknya pada usai muda dikarenakan kurangnya pengetahuan yang dimiliki oleh orang tua yang melangsungkan perkawinan muda di desa Setialaksana terhadap perkawinan. Mereka tidak begitu memikirkan bagaimanakah keadaan anaknya setelah berumah tangga yang penting bagi mereka anaknya sudah menikah dan sudah ada yang mau menanggung kebutuhan anak perempuannya serta orang tua berharap dari perkawinan yang telah dilangsungkannya itu 
anaknya itu dapat membantu kebutuhan orang tuanya. Setelah dilakukan penelitian maka didapatkan hasil faktor yang mempengaruhi paling banyak ialah faktor orang tua.

\section{Lampiran 1}

SCENE: 1. Kantor Kepala Desa

\section{SCENE: 2. Peta Desa Setialaksana}
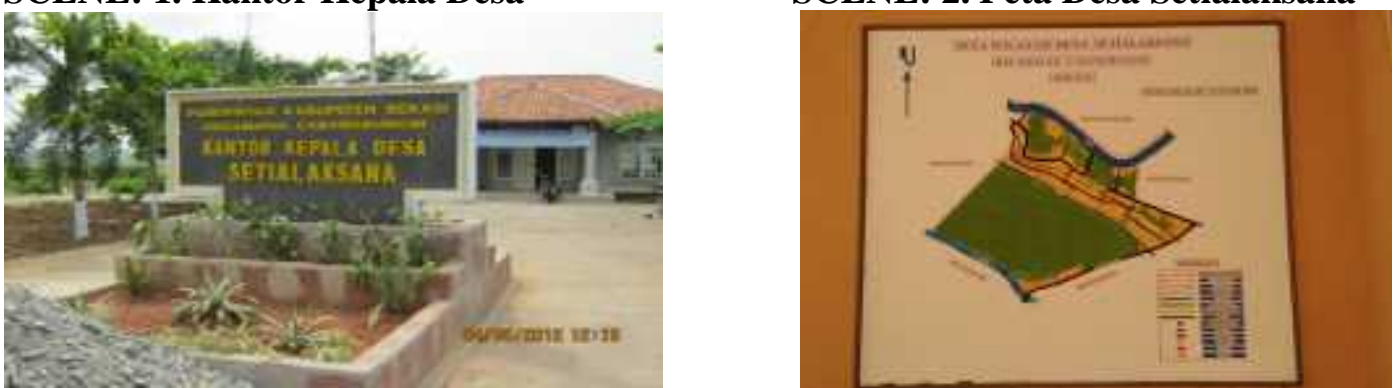

SCENE: 3. Foto peneliti dengan para Staf Desa Setialaksana

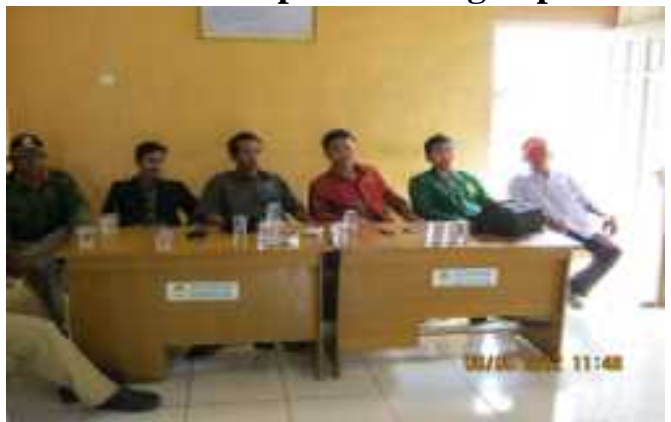

\section{Lampiran 2}

SCENE: 4. Foto peneliti dengan para informan, dan orangtuanya
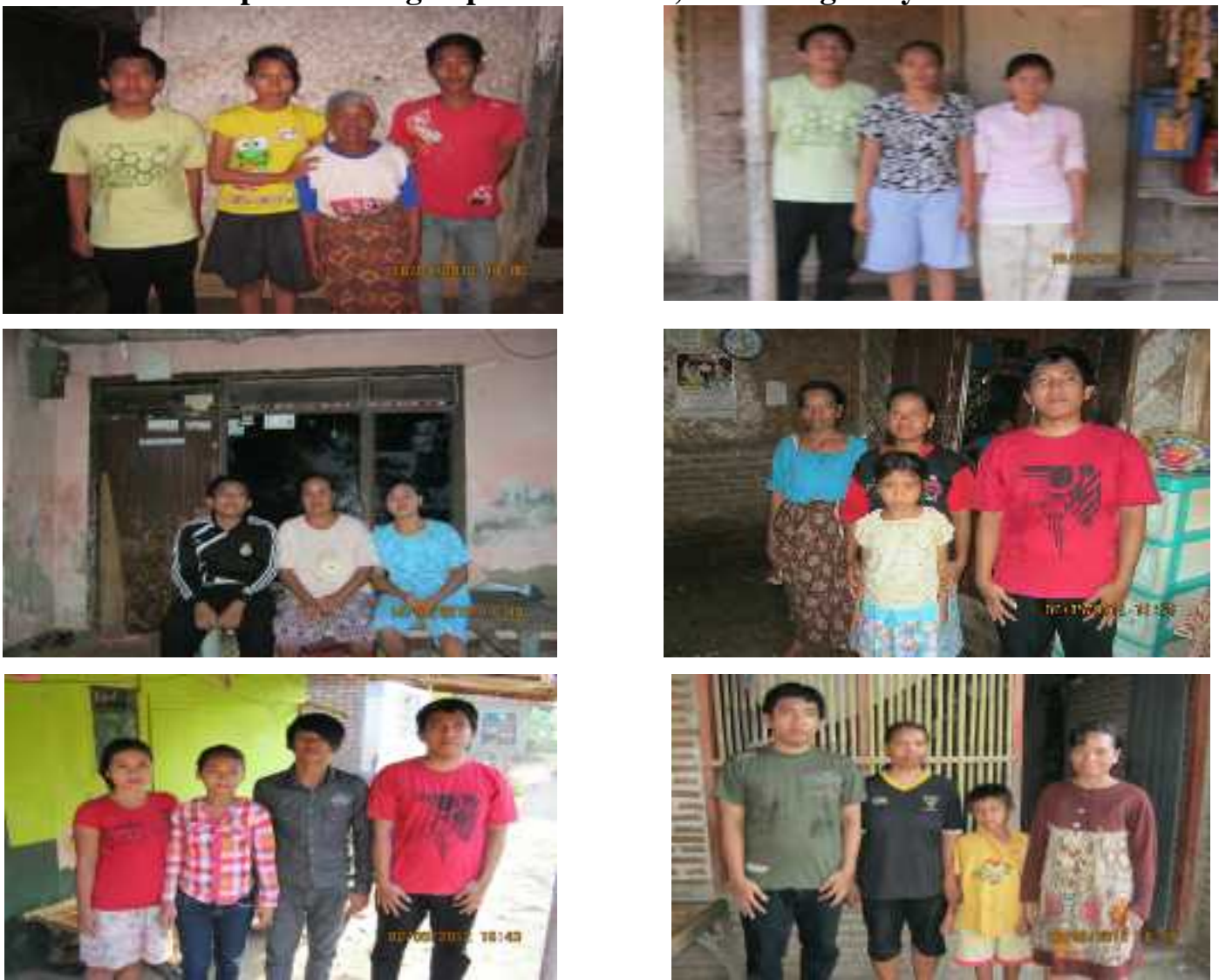

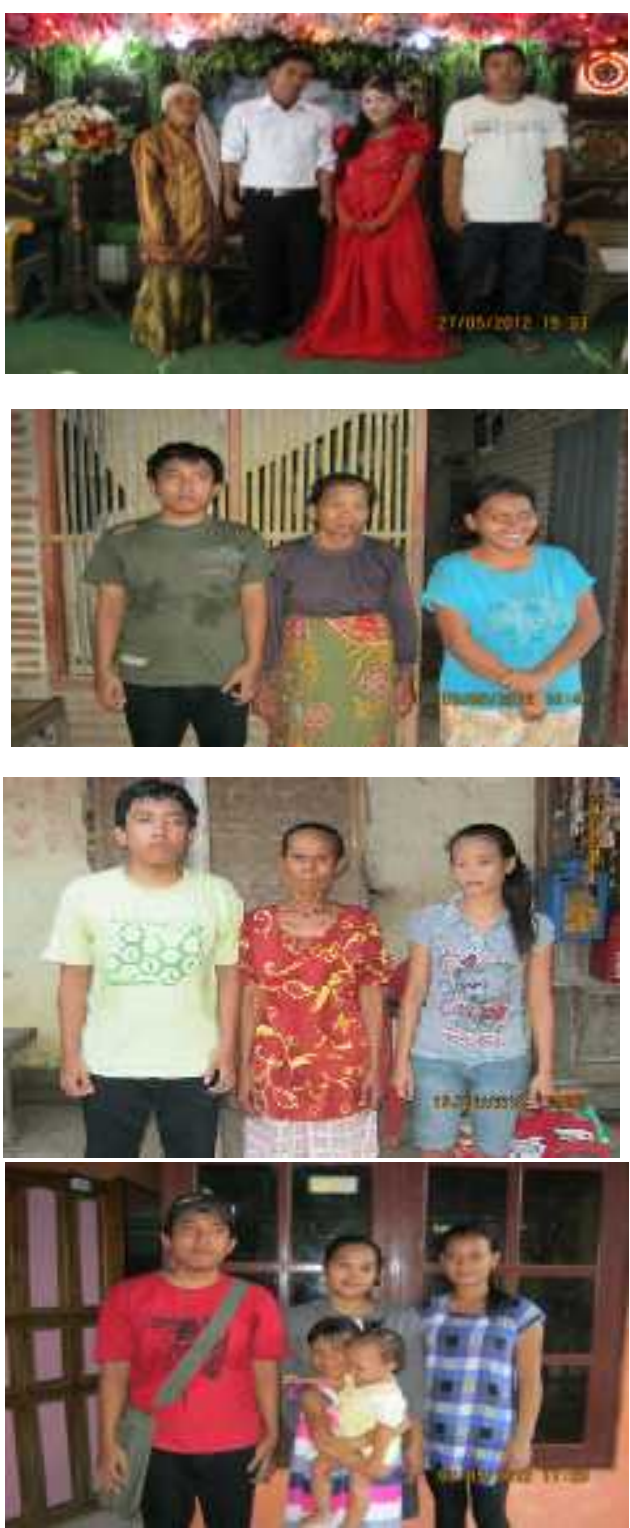

SCENE: 5. Triangulasi Expert Opinion

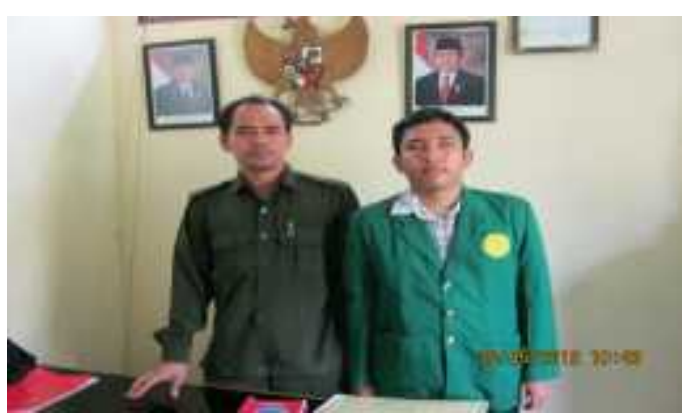

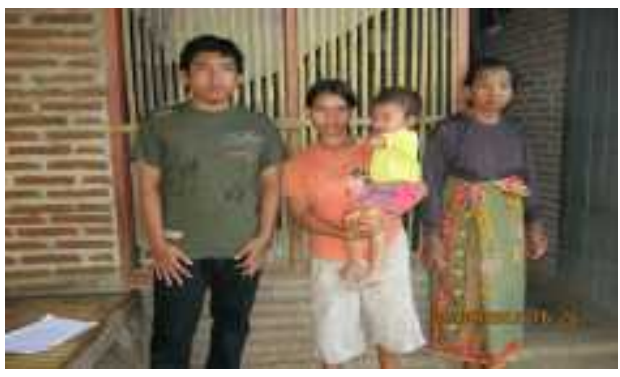
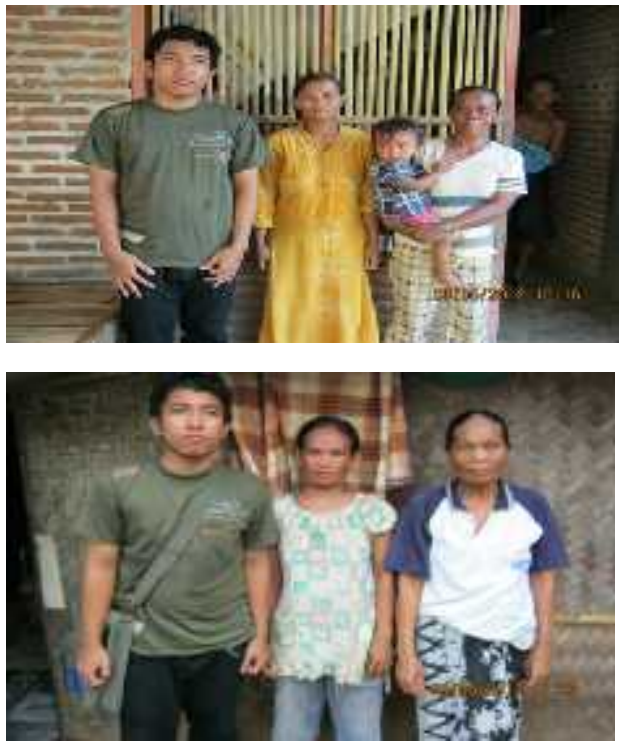

SCENE 6. Kantor KUA Cabangbungin

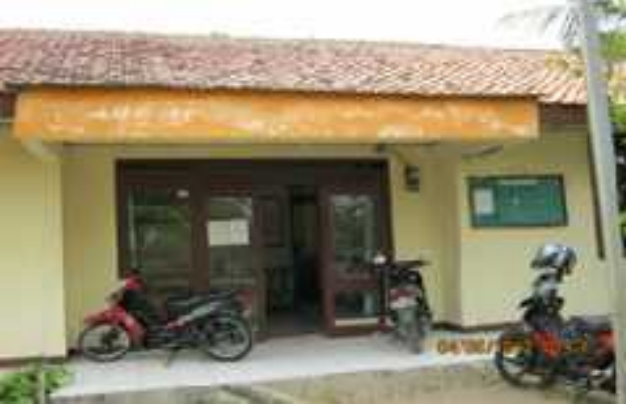




\section{KESIMPULAN DAN SARAN}

\section{Kesimpulan}

Faktor-faktor yang mempengaruhi terjadinya perkawinan pada usia muda di lokasi penelitian ini antara lain: faktor ekonomi, faktor keluarga, faktor pendidikan, faktor kemauan sendiri, dan faktor adat setempat. Faktor ekonomi, keluarga yang masih hidup dalam keadaan sosial ekonominya rendah/belum bisa mencukupi kebutuhan hidup sehari-hari. Faktor pendidikan, karena rendahnya tingkat pendidikan maupun pengetahuan orang tua, anak, akan pentingnya pendidikan. Faktor keluarga yaitu orang tua mempersiapkan atau mencarikan jodoh untuk anaknya. Faktor kemauan sendiri, karena pergaulan bebas sehingga mereka melakukan pernikahan. faktor adat yang menyebabkan terjadinya pernikahan usia muda karena ketakutan orang tua terhadap gunjingan dari tetangga dekat. Apabila anak perempuan belum takut anaknya dikatakan perawan tua.

Remaja yang memutuskan untuk menikah di usia muda pada umumnya beranggapan bahwa pendidikan bagi mereka adalah formalitas, sehingga mereka lebih mementingkan untuk berumahtangga daripada melanjutkan pendidikan yang lebih tinggi. Bahkan kebanyakan dari remaja yang menikah di usi muda rela meninggalkan bangku sekolah.

Dampak yang timbul dari perkawinan usia muda meliputi: dampak pada suami istri yaitu terjadinya pertengkaran dan percekcokan kecil dalam rumah-tangganya, dampak pada anak-anaknya yaitu rendahnya tingkat kecerdasan dan IQ pada anak serta adanya gangguangangguan pada perkembangan fisik anak. Dampak terhadap masing-masing keluarga apabila perkawinan diantara anak-anaknya tidak lancar maka orang tua akan merasa kecewa dan prihatin atas kejadian tersebut. Sebaliknya apabila perkawinannya lancar maka akan menguntungkan orang tuanya.

Pola asuh yang diterapkan oleh pasangan yang menikah pada usia muda di Desa Setialaksana kecamatan Cabangbungin Kabupaten Bekasi, kebanyakan menerapkan pola asuh demokratik.

\section{Saran}

Berdasarkan hasil penelitian ini dapat diberikan saran sebagai berikut:

1. Bagi remaja hendaknya lebih memahami faktor-faktor dan dampak dari perkawinan usia muda sehingga diharapkan remaja mempunyai pandangan dan wawasan yang dapat diaplikasikan dalam kegiatan yang bersifat positif pada wadah karang taruna.

2. Bagi pasangan yang belum menikah sebaiknya lebih memperhatikan dampak yang akan timbul akibat perkawinan pada usia muda dengan mengikuti pelatihan dan pembelajaran tentang perkembangan psikologis anak dan kesehatan anak baik di puskesmas maupun di posyandu.

3. Pola asuh demokratis harus diwujudkan dalam pola asuh anak dengan melibatkan dan memotivasi anak pada setiap kegiatan keluarga sehingga terbina keluarga yang harmonis. 


\section{DAFTAR PUSTAKA}

[1] http://www.halaman.web.id/profil-kawasan-industri/jawa-barat/profil-provinsi-jawa-barat2/ Diakses tanggal 26 April 2016. Jam 12.27 WIB.

[2] Sunarto, HM, M.Pd, Drs. 2007. Bahan Penyuluhan BKR Tentang Materi Ketahanan Keluarga Bagi Calon Pengantin. Jakarta: Badan Kependudukan dan Keluarga Berencana Nasional (BkkbN).

[3] Abidin, Zainal. 2009. Keluarga Sakinah. Daerah Istimewa Yogyakarta (DIY): Badan Penasihatan Pembinaan dan Pelestarian Perkawinan (BP4).

[4] Adhim Fauzil, Mohammad. 2006. Indahnya Perkawinan Dini. Jakarta: Gema Insani.

[5] Santrock, John W. 2003. Adoleschence (Perkembangan Remaja). Jakarta: Erlangga.

[6] Hurlock, Elizabeth B. 2006. Psikologis Perkembangan Sepanjang Rentang Kehidupan. Jakarta: Erlangga.

[7] Kertamuda, Fatchia E. 2009. Konseling Pernikahan untuk Keluarga Indonesia. Jakarta: Salemba Humanika.

[8] Dariyo, Agus. 2008. Psikologi Perkembangan Dewasa Muda. Jakarta: Gramedia Widya Sarana Indonesia.

[9] Siswanto, Wilopo, A. 2004. Ada Apa Dengan Gender. Jakarta:Badan Kependudukan dan Keluarga Berencana Nasional (BkkbN).

[10] Shochib, Moh. 2006. Pola Asuh Orangtua (Dalam Membantu Anak Mengembangkan Disiplin Diri), Jakarta: PT Rineka Cipta.

[11] http://www.jurnal-unita.org/index.php/publiciana/article/view/42/38. Diakses pada tanggal 20 Juli 2017.

[12] http://lib.unnes.ac.id/3749/. Diakses pada tanggal 20 Juli 2017.

[13] https://jurnal.usu.ac.id/index.php/ws/article/view/2140. Diakses pada tanggal $20 \mathrm{Juli}$ 2017.

[14] Hasil wawancara dengan Kepala Desa Setialaksana tentang data penduduk dan tingkat pendidikan masyarakat, Tahun 2011. 